https://doi.org/10.30836/igs.1025-6814.2020.2.198791

УДК 502.76(624.131.1)(477)

\title{
Л.В. САМОЙЛЕНКО
}

Інститут геологічних наук НАН України, Київ, Україна, E-mail: samoilenko2017@ukr.net

\section{ГЕОЛОГІЧНІ ПАМ'ЯТКИ ПРИРОДИ ЯК ОБ'ЄКТИ ПРИРОДНО-ЗАПОВІДНОГО ФОНДУ (ПРОБЛЕМНІ ПИТАННЯ)}

На підставі даних Державного кадастру територій та об’єктів природно-заповідного фонду Украӥни встановлено особливості розподілу геологічних об'єктів по адміністративно-територіальних одинииях за категоріями, типами об'єктів, значенням та ступенем иінності. Найбільша частка геологічних від загальної кількості оголошених пам'яток природи відмічається у Житомирській, Чернівецькій та Донецькій областях. Проаналізовано порядок оголочення геологічних пам'яток та запропоновано оптимізацію співпраці з відповідними державними органами щодо їх популяризації, охорони та збереження. Під час оголошення об'єкт природно-заповідного бонду на законодавчому рівні отримує категорію - «пам'ятка природи», тип за походженням - «геологічна». Залежно від значення (загальнодержавне чи місиеве) та иінності (міжнародна, національна, регіональна, місцева) геологічної пам'ятки природи встановлюється режим їі охорони. За иции ознаками об'єкт вноситься до Державного кадастру територій та об'єктів природно-заповідного фонду. 3 метою узгодження існуючих класифікацій різних авторів із законодавчими та нормативно-правовими актами щзодо природно-заповідного фонду України пропонується наступне. За геоморфологічну ознаку підтипу геологічних пам'яток прийняти унібіковану назву морбоскульптури, що вказана в Державному кадастрі, та встановити п'ять підтипів: останець; відслонення; підземна порожнина; водний об’єкт; інші. За ознаку класу прийняти інженерно-геологічні характеристики порід пам'ятки, від яких залежить інтенсивність руйнування та, відповідно, напрям охоронних заходів: легкорозмивні; легкорозмокаючі; легкорозчинні; середньої міиності; міцні. За інженерно-геологічними процесами, щзо спричинили розкриття пам'ятки, встановити підкласи: денудаційні; ерозійно-денудаційні; ерозійні; абразійні, карстово-субозійні; техногенні тощо. Доцільний подальший поділ геологічних пам'яток за предметом досліджень: мінералогічний, петрографічний, літологічний, стратиграфічний, палеонтологічний тощо, щзо пропонують також інші автори.

Ключові слова: геологічні пам'ятки природи; об'єкти природно-заповідного фонду; Державний кадастр; класифікація.

\section{Ветуп}

Вивчення “геологічних пам'яток” - відносно новий напрям геологічних досліджень, якому властиві проблеми, пов'язані із формуванням понятійно-термінологічної бази та її узгодженням із чинними законами та підзаконними ак- тами. Фахівці-геологи можуть називати “геологічна пам'ятка” будь-який об’єкт, що, на їх думку, відповідає цій назві, проте статус об'єкта природно-заповідного фонду (далі ПЗФ) він отримає лише після оголошення заказником чи пам'яткою природи на підставі

Ци т у в ан н я: Самойленко Л.В. Геологічні пам’ятки природи як об’єкти природно-заповідного фонду (проблемні питання). Геологічний журнал. 2020. № 2 (371). С. 52-62. https://doi. 10.30836/igs.1025-6814.2020.2.198791

Citation: Samoilenko L.V., 2020. Geosites as objects of natural reserve fund (problematic issues). Geological Journal (Ukraine), No. 2 (371), pp. 52-62. https://doi.org/10.30836/igs.1025-6814.2020.2.198791 
Указу Президента України (об’єкт загальнодержавного значення) чи рішення обласної ради (об’єкт місцевого значення) відповідно до Закону України “Про ПЗФ України”. Статус об'єкта ПЗФ із встановленням охоронних зон та відповідного режиму охорони є важливою умовою збереження та популяризації геологічної спадщини. Розробляючи, поглиблюючи та вдосконалюючи визначення та класифікації “геологічних пам'яток”, також необхідно зважати на встановлені цим же законом категорії та типи об'єктів. Показовим щодо відношення до охорони і збереження геологічної спадщини $є$ сучасний стан заповідання геологічних об’єктів у різних регіонах країни.

Тому у цій роботі значна увага приділена узгодженню різних класифікацій “геологічних пам'яток” із законодавчою і нормативно-правовою базою, офіційними відомостями щодо геологічних об'єктів ПЗФ; аналізу сучасного стану цих відомостей; пропозиціям щодо покращення ситуації із визнанням на державному та регіональному рівнях унікальності геологічних об’єктів, необхідності їх збереження та популяризації.

\section{Стан проблеми}

Значна кількість визначень терміну “геологічні пам'ятки” (geosites aбo landmarks), що зустрічаються в різних публікаціях (Самойленко, Дубицька, 2012; Палюх, 2010), досить вдало узагальнені на сайті Держгеонадр як "унікальні об'єкти природного походження, що найбільш повно і наочно характеризують перебіг геологічних процесів та їх результати, мають наукову цінність і доступні для безпосереднього спостереження і дослідження" (http:// geonews.com.ua/geologichni_pamiatki_ukraini). Відповідно до Закону України "Про ПЗФ України”, заказниками оголошуються природні території, а пам'ятками природи - окремі унікальні природні утворення, що мають особливе природоохоронне, наукове, естетичне, пізнавальне і культурне значення, з метою збереження їх у природному стані. Крім того, законом передбачено, що пам'ятки природи можуть розташовуватися на території інших об'єктів ПЗФ.

Відомості про оголошені заказники та пам'ятки природи вносяться до Державного кадастру територій та об'єктів ПЗФ (далі Кадастр), який ведеться Міністерством енергетики та захисту довкілля України (далі Мінекоенергетики) та обласними державними адміністраціями.

Створена УкрДГРІ база даних геологічних пам'яток України налічує 642 об'єкта, які тим чи іншим чином становлять інтерес в якості геологічної спадщини нашої країни (Карта..., 2019). Проте офіційно оголошених геологічних пам'яток природи та заказників (геологічних та карстово-спелеологічних) в Кадастрі налічується близько 460. Навіть, якщо деяка частина об'єктів з ознаками геологічних (водоспади) чи гідрогеологічних (джерела, болота тощо) оголошені гідрологічними чи комплексними пам'ятками, залишається значна кількість, що не відноситься до ПЗФ, відповідно, не підлягає охороні на рівні держави та знаходиться під потенційною загрозою руйнування внаслідок антропогенного впливу. Земельні ділянки з геологічними об'єктами, як правило, передаються у приватну власність чи надаються у користування i, у разі відсутності статуту об'єкта ПЗФ, спокійно руйнуються внаслідок господарської діяльності (Вертель, 2015).

\section{Мета досліджень}

На підставі аналізу законодавчої та нормативно-правової бази, сучасного стану офіційних відомостей щодо геологічних об’єктів ПЗФ узгодити існуючі класифікації “геологічних пам'яток” із законодавчою та нормативно-правовою базою та відомостями Кадастру, встановити стан надання геологічним об'єктам статуту об'єктів ПЗФ у різних регіонах України та запропонувати шляхи покращення ситуації щодо визнання цінності і необхідності збереження об'єктів геологічної спадщини на рівні держави.

\section{Матеріали та методи}

Дослідження опиралися на Закон України “Про ПЗФ України” (Про природно..., 1992), Інструкцію про зміст та складання документації державного кадастру територій та об’єктів ПЗФ України (Про затвердження..., 2005), Методичні рекомендації щодо розробки положень про території та об’єкти ПЗФ України 
(Про затвердження..., 2018), Методичні рекомендації щодо розроблення проектів створення природних територій та об'єктів ПЗФ України (Про затвердження..., 2018), що регулюють суспільні відносини щодо організації, охорони і використання територій та об'єктів ПЗФ. Оцінка сучасного стану відомостей щодо геологічних об'єктів ПЗФ виконувалась на основі аналізу та систематизації інформації 3 Кадастру (Державний кадастр..., 2013) та звітності “Форма 4 ДКПЗФ” (Форма..., 2017) щодо геологічних об’єктів ПЗФ.

\section{Результати}

\section{Уніфікована класифікація у складі понятійно-термінологічної бази}

Стаття 3 Закону України “Про ПЗФ України”, що так і називається "Класифікація територій та об’єктів природно-заповідного фонду України", визначає такі категорії: природні заповідники, біосферні заповідники, національні природні парки, регіональні ландшафтні парки, заказники, пам'ятки природи, заповідні урочища. Із перелічених категорій передбачається розподіл об'єктів за типами залежно від походження (тобто за генетичними ознаками), інших особливостей та необхідного режиму охорони. Заказників - на ландшафтні, лісові, ботанічні, загальнозоологічні, орнітологічні, ентомологічні, іхтіологічні гідрологічні, загальногеологічні, палеонтологічні, карстово-спелеологічні; пам'яток природи - на комплексні, пралісові, ботанічні, зоологічні, гідрологічні та геологічні. Комплексні пам'ятки можуть мати ознаки різних типів. Тобто, ні “геоморфологічний”, ні “гідрогеологічний”, ні інші типи об'єктів ПЗФ, крім вищезгаданих, не передбачені чинним законодавством.

Екологічна, наукова, історико-культурна цінність об'єктів ПЗФ визначає їх значення загальнодержавне або місцеве (Про природно..., 1992). Ступінв иінності об'єкта ПЗФ визначається Інструкцією про зміст та складання документації Державного кадастру територій та об’єктів ПЗФ України (Про затвердження..., 2005), як міжнародна (території водно-болотних угідь, збереження яких має світове та Європейське значення); національна (видатні пам'ятки природи, в тому числі печери), регіональна (території, що мають регіо- нальну оздоровчо-рекреаційну цінність), місцеева (об'єкти ПЗФ, не віднесені до перших трьох категорій, зокрема геологічні пам'яткискелі). Об'єкти загальнодержавного значення мають міжнародну та національну, а об'єкти місиевого значення - регіональну та місцеву cmyniнв цінності. Тому зауваження деяких авторів (Люта та ін., 2012) щодо “легітимності детальнішої градації значення пам'яток” за значенням і ступенем цінності не зовсім слушні. Критерії, за якими об’єкти ПЗФ віднесені до цих категорій, хоч не детально, але викладені у нормативно-правових документах (Про природно..., 1992; Про затвердження..., 2005).

Подальша деталізація пам'яток природи у Кадастрі пов'язана з їх назвою, що часто містить ознаку морфоскульптури об'єкта. При цьому до геологічного типу віднесено пам'ятки під назвами: відслонення, виходи (Дніпропетровська область), оголення (Донецька, Луганська області), зразок розрізу (Хмельницька область), геологічний розріз (Київська область), каньйон (Хмельницька область), кар'єр (Запорізька область), скеля, камінь, виступи (ІваноФранківська, Миколаївська області), залізорудна штольня (Закарпатська область), метеоритний кратер (Вінницька область), нафтова свердловина (Львівська область), катакомби (Одеська область), карстові лійки, місце знахідки решток мамонта (Тернопільська область), печера-грот. У Чернівецькій області, на відміну від інших, до геологічних пам'яток віднесено і водоспади. Ключі, озера, болота, ставки, витоки річок, джерела, свердловини, водоспади, тобто об'єкти, що деякі автори пропонують віднести до гідрогеологічних (Люта та ін., 2012), внесені до Кадастру по всіх областях, крім Чернівецької, як гідрологічні пам'ятки.

Тому доцільно виконати подальший розподіл типів пам'яток на підтипи за морфоскульптурою, уніфікуючи їх назви. Всі наведені у Кадастрі “варіанти” морфоскульптур можна звести до п’яти підтuniв: 1 - останець (скеля, камінь тощо); 2 - відслонення (оголення, зразок, розріз, вихід, стінка тощо); 3 - підземна порожнина (печера, катакомби, штольня); $4-$ водний об’єкт (каньйон, водоспад, джерело); 5 - інші (метеоритний кратер тощо).

В дужках наведені “назви”, часто некоректні з точки зору геологічної термінології, але офіційно закріплені за геологічними об'єктами 
ПЗФ та внесені до Кадастру. Так підтип “відслонення” включає пам'ятки, “де корінні породи виходять на поверхню і не перекриваються більш молодими відкладами" (https:// geodictionary.com.ua/node/1983), внесені до Кадастру також як "оголення - невдалий переклад з російської (“Киселівські оголення” в Луганській області, “Оголення нижнього карбону” в Донецькій області), “розріз” тощо. До речі, під назвою "розріз”, що відповідно до геологічного словника $\epsilon$ "графічним зображенням на вертикальній площині”, яке “доповнює та уточнює геологічну карту” (https://geodictionary. com.ua/node/3870), до Кадастру внесена значна кількість геологічних пам'яток в різних регіонах України. Таке положення з назвами свідчить, в першу чергу, про відсутність закріпленої на нормативно-правовому рівні термінології щодо об’єктів ПЗФ та участі фахівцівгеологів у підготовці (погодженні, експертизі) матеріалів до заповідання геологічних об’єктів.

Крім геоморфологічних факторів стан збереження пам'яток, напрямок та інтенсивність ïх руйнування, можливий термін існування визначають також природно-техногенні процеси та фізико-механічні властивості грунтів (Демчишин та ін., 2011; Самойленко, Дубицька, 2011). Тому, поглиблюючи класифікацію геологічних пам'яток, автори пропонують підтипи поділити на п'ять класів за інженерногеологічними характеристиками порід, що складають пам'ятку: 1 - легкорозмивні (піски, пухкі суглинки тощо); 2 - легкорозмокаючі (лесові породи); 3 - легкорозчинні (карбонатні, сульфатні, породи із карбонатним цементом, солі); 4 - середньої міцності (глини, мергелі, глинисті пісковики); 5 - міцні (слабовивітрені інтрузивні масиви, магматичні і метаморфічні породи). Класи пам'яток доцільно поділяти на підкласи за інженерно-геологічними процесами, що спричинили їх розкриття: 1 - денудаційні; 2 - ерозійно-денудаційні (відслонення в долині тимчасового водотоку в яру чи балці); 3 - ерозійні (відслонення на схилі річкової долини); 4 - утворені внаслідок переробки берегів водойми (відслонення на березі водосховища); 6 - абразійні; 7 - карстово-суфозійні; 8 - техногенні (відслонення борту кар'єру, катакомби, штольні) тощо.

Що ж до подальшої градації геологічних пам'яток, можна погодитись із класифікацією за предметом досліджень: мінералогічний, петрографічний, літологічний, стратиграфічний, палеонтологічний тощо (Люта та ін., 2012; Caмойленко, Дубицька, 2012).

\section{Розподіл геологічних об'сктів ПЗФ по регіонах}

Відповідно до Кадастру об’єктами ПЗФ загальнодержавного значення оголошено п'ять геологічних (загальногеологічних) заказників (два в Криму та по одному у Закарпатській, Запорізькій та Донецькій областях) загальною площею 6049 га; два карстово-спелеологічних (Чернівецька область), що займають 69 га; та 39 гідрологічних площею 55101 га. Лише гідрологічний заказник "Молочний лиман” у Запорізькій області займає площу 19000 га. Геологічних пам'яток природи загальнодержавного значення налічується 33 (639 га), гідрологічних - 21 (511 га) (табл. 1).

До об’єктів місцевого значення віднесено 10 загальногеологічних заказників (чотири у Рівненській області, два у Сумській та по одному у Волинській, Житомирській, Харківській, Хмельницькій областях) загальною площею 2604 га; один карстово-спелеологічний (Чернівецька область) площею 12 га; 673 гідрологічних (142897 га), із яких переважна кількість - 260 загальною площею 55936 га знаходиться у Чернігівській області. Геологічних пам'яток природи місцевого значення налічується 409 (1457 га), гідрологічних - 707 (3814 га).

Розподіл геологічних об'єктів ПЗФ по адміністративно-територіальних одиницях наведено на рис. 1 та 2. Найбільша частка геологічних пам'яток від усіх оголошених пам'яток природи (табл. 2) знаходиться у Житомирській (41 \% від кількості та 9 \% від площі), Чернівецькій (30 \% від кількості та 45 \% від площі), Донецькій (38 \% від кількості та 20 \% від площі) областях. Відсутні офіційно оголошені геологічні пам'ятки у Харківській та Волинській областях. Низька питома вага геологічних пам'яток (до 4 \%) у Херсонській, Чернігівській та Миколаївській областях. Питома вага геологічних заказників разом із карстово-спелеологічними за кількістю та площею досягає лише у Криму 5 \%, Рівненській області $3 \%$, Чернівецькій за кількістю $5 \%$, а за площею 0,18 \%. Загалом по Україні питома вага геологічних та карстово-спелеологічних заказни- 
乌ू Таблиця 1. Розподіл кількості та площі об’єктів ПЗФ України по адміністративно-територіальних одиницях (за даними Кадастру)

Table 1. Distribution of the number and area of the objects of the Nature reserve fund of Ukraine by administrative-territorial units (according to the Cadaster data)

\begin{tabular}{|c|c|c|c|c|c|c|c|c|c|c|c|c|c|c|c|c|c|c|c|c|}
\hline \multirow{3}{*}{$\begin{array}{l}\text { Адміністративно- } \\
\text { територіальна } \\
\text { одиниця }\end{array}$} & \multicolumn{4}{|c|}{ Карстово-спелеологічні заказники } & \multicolumn{4}{|c|}{ Загальногеологічні заказники } & \multicolumn{4}{|c|}{ Гідрологічні заказники } & \multicolumn{4}{|c|}{ Геологічні пам’ятки } & \multicolumn{4}{|c|}{ Гідрологічні пам'ятки } \\
\hline & \multicolumn{2}{|c|}{$\begin{array}{c}\text { Загально- } \\
\text { державного } \\
\text { значення }\end{array}$} & \multicolumn{2}{|c|}{$\begin{array}{c}\text { Місцевого } \\
\text { значення }\end{array}$} & \multicolumn{2}{|c|}{$\begin{array}{c}\text { Загально- } \\
\text { державного } \\
\text { значення }\end{array}$} & \multicolumn{2}{|c|}{$\begin{array}{c}\text { Місцевого } \\
\text { значення }\end{array}$} & \multicolumn{2}{|c|}{$\begin{array}{c}\text { Загально- } \\
\text { державного } \\
\text { значення }\end{array}$} & \multicolumn{2}{|c|}{$\begin{array}{c}\text { Місцевого } \\
\text { значення }\end{array}$} & \multicolumn{2}{|c|}{\begin{tabular}{|} 
Загально- \\
державного \\
значення
\end{tabular}} & \multicolumn{2}{|c|}{$\begin{array}{c}\text { Місцевого } \\
\text { значення }\end{array}$} & \multicolumn{2}{|c|}{$\begin{array}{c}\text { Загально- } \\
\text { державного } \\
\text { значення }\end{array}$} & \multicolumn{2}{|c|}{$\begin{array}{c}\text { Місцевого } \\
\text { значення }\end{array}$} \\
\hline & 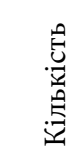 & 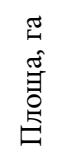 & 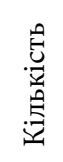 & 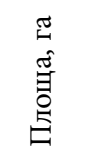 & 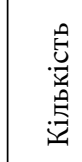 & 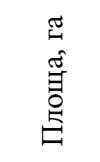 & 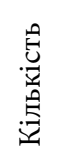 & 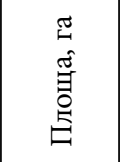 & 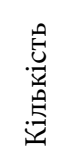 & 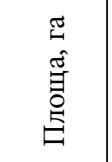 & 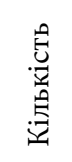 & 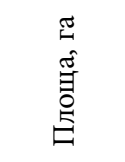 & 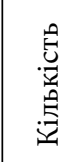 & 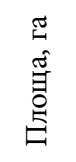 & 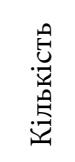 & 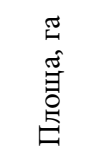 & 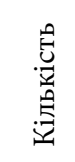 & 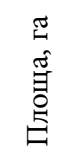 & 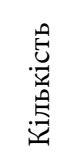 & 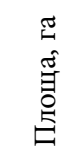 \\
\hline Вінницька & & & & & & & & & & & 16 & 1633 & 4 & 98 & 15 & 28 & & & 60 & 1 \\
\hline Волинська & & & & & & & 1 & 90 & & & 59 & 24209 & & & & & 2 & 90 & 16 & 116 \\
\hline Дніпропетровська & & & & & & & & & & & 1 & 22 & 1 & 62 & 12 & 40 & & & 2 & 2 \\
\hline Донецька & & & & & 1 & 100 & & & & & & & 5 & 111 & 10 & 31 & 2 & 62 & 7 & 9 \\
\hline Житомирська & & & & & & & 1 & 15 & 3 & 2194 & 27 & 8167 & & & 15 & 13 & & & 3 & 0 \\
\hline Закарпатська & & & & & 1 & 150 & & & 1 & 105 & 4 & 851 & & & 38 & 174 & 1 & 15 & 250 & 216 \\
\hline Запорізька & & & & & 1 & 1383 & & & 1 & 19000 & & & 2 & 30 & 11 & 63 & & & & \\
\hline Івано-Франківська & & & & & & & & & 1 & 255 & 5 & 3973 & 1 & 60 & 15 & 27 & 4 & 33 & 15 & 21 \\
\hline Київська & & & & & & & & & 3 & 5448 & 11 & 3192 & & & 5 & 26 & & & 3 & 179 \\
\hline Кіровоградська & & & & & & & & & 1 & 568 & & & & & 3 & 10 & 1 & 2 & 10 & 56 \\
\hline АР Крим & & & & & 2 & 4416 & & & 1 & 250 & 1 & 1000 & 4 & 73 & 22 & 43 & 1 & 24 & 15 & 1980 \\
\hline Луганська & & & & & & & & & & & 2 & 4293 & 1 & 20 & 14 & 59 & & & 21 & 14 \\
\hline Львівська & & & & & & & & & 2 & 281 & 1 & 54 & & & 19 & 191 & & & 33 & 12 \\
\hline Миколаївська & & & & & & & & & & & 6 & 1978 & & & 7 & 33 & & & 13 & 27 \\
\hline Одеська & & & & & & & & & & & & & 1 & 5 & 1 & 0 & & & 6 & 1 \\
\hline Полтавська & & & & & & & & & 7 & 6543 & 51 & 9392 & & & 9 & 46 & & & 3 & 2 \\
\hline Рівненська & & & & & & & 4 & 2460 & 2 & 3304 & 11 & 2442 & & & 2 & 3 & 2 & 73 & 13 & 56 \\
\hline Сумська & & & & & & & 2 & 18 & 5 & 11230 & 26 & 9614 & & & 5 & 13 & 1 & 7 & 35 & 70 \\
\hline Тернопільська & & & & & & & & & 2 & 1356 & 10 & 576 & 7 & 0 & 76 & 125 & & & 63 & 70 \\
\hline Харківська & & & & & & & 1 & 15 & & & 17 & 1812 & & & & & & & 4 & 14 \\
\hline Херсонська & & & & & & & & & & & & & & & 1 & 1 & & & 4 & 5 \\
\hline Хмельницька & & & & & & & 1 & 7 & 5 & 1131 & 47 & 8827 & 3 & 150 & 45 & 148 & 1 & 8 & 13 & 84 \\
\hline Черкаська & & & & & & & & & 1 & 940 & 118 & 4926 & & & 30 & 52 & & & 34 & 61 \\
\hline Чернівецька & 2 & 69 & 1 & 12 & & & & & & & & & 4 & 31 & 50 & 320 & & & 52 & 54 \\
\hline Чернігівська & & & & & & & & & 4 & 2556 & 260 & 55936 & & & 4 & 14 & 6 & 197 & 24 & 334 \\
\hline м. Київ & & & & & & & & & & & & & & & & & & & 4 & 0 \\
\hline м. Севастополь & & & & & & & & & & & & & & & & & & & 4 & 431 \\
\hline Разом: & 2 & 69 & 1 & 12 & 5 & 6049 & 10 & 2604 & 39 & 55161 & 673 & 142897 & 33 & 639 & 409 & 1457 & 21 & 511 & 707 & 3814 \\
\hline
\end{tabular}




\begin{tabular}{|c|c|c|c|c|c|c|c|c|c|c|c|c|c|c|c|c|}
\hline \multirow{3}{*}{$\begin{array}{c}\text { Адміністративно- } \\
\text { територіальна } \\
\text { одиниця }\end{array}$} & \multicolumn{4}{|c|}{ Заказники (загальна кількість) } & \multicolumn{4}{|c|}{ Пам’ятки природи (загальна кількість) } & \multicolumn{4}{|c|}{ Питома вага заказників, \% } & \multicolumn{4}{|c|}{ Питома вага пам’яток природи, \% } \\
\hline & \multicolumn{2}{|c|}{\begin{tabular}{|c} 
Загальнодержав \\
значення \\
\end{tabular}} & \multicolumn{2}{|c|}{$\begin{array}{c}\text { Місцевого } \\
\text { значення }\end{array}$} & \multicolumn{2}{|c|}{$\begin{array}{c}\text { Загальнодержав. } \\
\text { значення }\end{array}$} & \multicolumn{2}{|c|}{ Місцевого значення } & \multicolumn{2}{|c|}{$\begin{array}{c}\text { Геологічні + } \\
\text { + карстово- } \\
\text { спелеологічні }\end{array}$} & \multicolumn{2}{|c|}{$\begin{array}{l}\text { Геологічні + } \\
+ \text { гідрологічні }\end{array}$} & \multicolumn{2}{|c|}{ Геологічні } & \multicolumn{2}{|c|}{$\begin{array}{c}\text { Геологічні + } \\
\text { + гідрологічні }\end{array}$} \\
\hline & 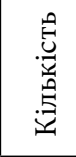 & 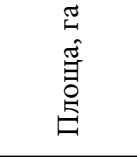 & 莆 & 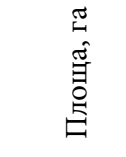 & 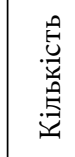 & 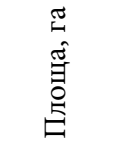 & 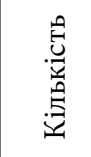 & 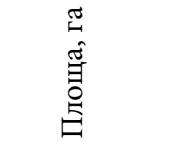 & 尤 & 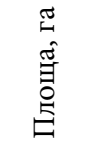 & 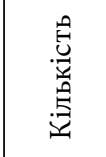 & 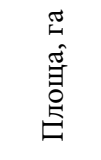 & 总 & 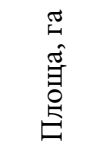 & 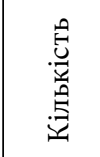 & 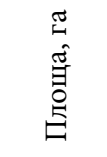 \\
\hline Вінницька & 21 & 13564 & 125 & 11398 & 10 & 322 & 185 & 653 & & & 10,96 & 6,54 & 9,74 & 12,84 & 40,51 & 12,95 \\
\hline Волинська & 15 & 7732 & 206 & 90783 & 4 & 123 & 120 & 455 & 0,45 & 0,09 & 27,15 & 24,67 & & & 14,52 & 35,66 \\
\hline Дніпропетровська & 24 & 29037 & 81 & 47959 & 3 & 148 & 50 & 357 & & & 0,95 & 0,03 & 24,53 & 20,20 & 28,30 & 20,50 \\
\hline Донецька & 7 & 4629 & 47 & 10141 & 10 & 236 & 30 & 469 & 1,85 & 0,68 & 1,85 & 0,68 & 37,50 & 20,08 & 60,00 & 30,17 \\
\hline Житомирська & 10 & 6757 & 145 & 78305 & 2 & 51 & 35 & 94 & 0,65 & 0,02 & 20,00 & 12,20 & 40,54 & 9,07 & 48,65 & 9,18 \\
\hline Закарпатська & 19 & 12368 & 55 & 7743 & 9 & 464 & 329 & 479 & 1,35 & 0,75 & 8,11 & 5,50 & 11,24 & 18,48 & 85,50 & 43,00 \\
\hline Запорізька & 12 & 38998 & 224 & 16561 & 7 & 412 & 77 & 580 & 0,42 & 2,49 & 0,85 & 36,69 & 15,48 & 9,40 & 15,48 & 9,40 \\
\hline Івано-Франківська & 10 & 5416 & 59 & 42965 & 14 & 440 & 200 & 911 & & & 8,70 & 8,74 & 7,48 & 6,44 & 16,36 & 10,44 \\
\hline Київська & 16 & 63277 & 85 & 26393 & 2 & 92 & 67 & 363 & & & 13,86 & 9,63 & 7,25 & 5,66 & 11,59 & 44,95 \\
\hline Кіровоградська & 21 & 5728 & 84 & 12819 & 2 & 9 & 50 & 525 & & & 0,95 & 3,06 & 5,77 & 1,78 & 26,92 & 12,59 \\
\hline АР Крим & 14 & 73958 & 25 & 23999 & 13 & 639 & 81 & 2580 & 5,13 & 4,51 & 10,26 & 5,78 & 27,66 & 3,59 & 44,68 & 65,84 \\
\hline Луганська & 5 & 1416 & 90 & 57154 & 3 & 165 & 68 & 5234 & & & 2,11 & 7,33 & 21,13 & 1,46 & 50,70 & 1,72 \\
\hline Львівська & 9 & 3303 & 35 & 27771 & 2 & 593 & 186 & 2241 & & & 6,82 & 1,08 & 10,11 & 6,73 & 27,66 & 7,13 \\
\hline Миколаївська & 1 & 1782 & 54 & 10658 & 1 & 11 & 43 & 286 & & & 10,91 & 15,90 & 15,91 & 11,08 & 45,45 & 20,17 \\
\hline Одеська & 8 & 11913 & 31 & 16440 & 2 & 10 & 47 & 11 & & & & & 4,08 & 23,41 & 16,33 & 26,36 \\
\hline Полтавська & 20 & 41227 & 156 & 38155 & 1 & 145 & 134 & 1733 & & & 32,95 & 20,07 & 6,67 & 2,44 & 8,89 & 2,57 \\
\hline Рівненська & 13 & 16720 & 112 & 53887 & 8 & 420 & 59 & 394 & 3,20 & 3,48 & 13,60 & 11,62 & 2,99 & 0,34 & 25,37 & 16,22 \\
\hline Сумська & 10 & 17780 & 93 & 29664 & 3 & 62 & 98 & 171 & 1,94 & 0,04 & 32,04 & 43,97 & 4,95 & 5,50 & 40,59 & 38,43 \\
\hline Тернопільська & 18 & 11938 & 113 & 50032 & 12 & 126 & 452 & 1256 & & & 9,16 & 3,12 & 17,89 & 9,00 & 31,47 & 14,03 \\
\hline Харківська & 3 & 1038 & 166 & 36922 & 0 & 0 & 44 & 646 & 0,59 & 0,04 & 10,65 & 4,81 & & & 9,09 & 2,23 \\
\hline Херсонська & 8 & 34607 & 13 & 26893 & 0 & 0 & 30 & 26 & & & & & 3,33 & 1,92 & 16,67 & 21,07 \\
\hline Хмельницька & 25 & 9661 & 133 & 27903 & 5 & 173 & 292 & 1521 & 0,63 & 0,02 & 33,54 & 26,53 & 16,16 & 17,57 & 20,88 & 23,02 \\
\hline Черкаська & 5 & 14014 & 217 & 28474 & 6 & 1166 & 186 & 721 & & & 53,60 & 13,81 & 15,63 & 2,76 & 33,33 & 5,99 \\
\hline Чернівецька & 10 & 1262 & 47 & 42875 & 9 & 176 & 175 & 607 & 5,26 & 0,18 & 5,26 & 0,18 & 29,35 & 44,84 & 57,61 & 51,74 \\
\hline Чернігівська & 11 & 9326 & 436 & 105356 & 7 & 297 & 130 & 562 & & & 59,06 & 51,00 & 2,92 & 1,63 & 24,82 & 63,45 \\
\hline Разом: & 320 & 464249 & 2847 & 925426 & 136 & 6312 & 3305 & 23457 & 0,57 & 0,63 & 23,05 & 14,88 & 12,85 & 7,04 & 34,00 & 21,57 \\
\hline
\end{tabular}




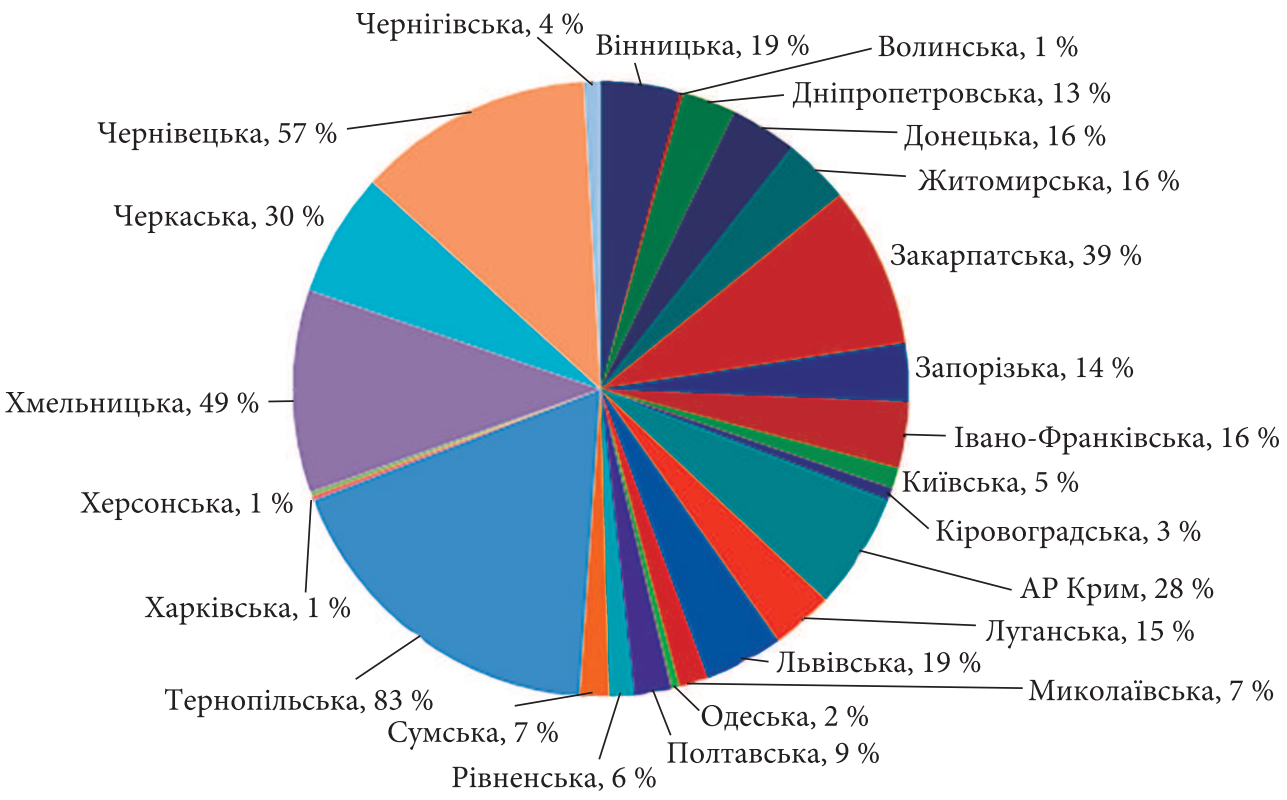

Рис. 1. Розподіл кількості геологічних об’єктів природно-заповідного фонду по областях (за даними Кадастру)

Fig. 1. Distribution of the number of geological objects of the Nature Reserve Fund by regions (according to the Cadaster data)

Рис. 2. Розподіл площі (га) геологічних об’єктів природно-заповідного фонду по областях (за даними Кадастру)

Fig. 2. Distribution of areas of geological objects of the NRF by regions (according to the Cadaster data)

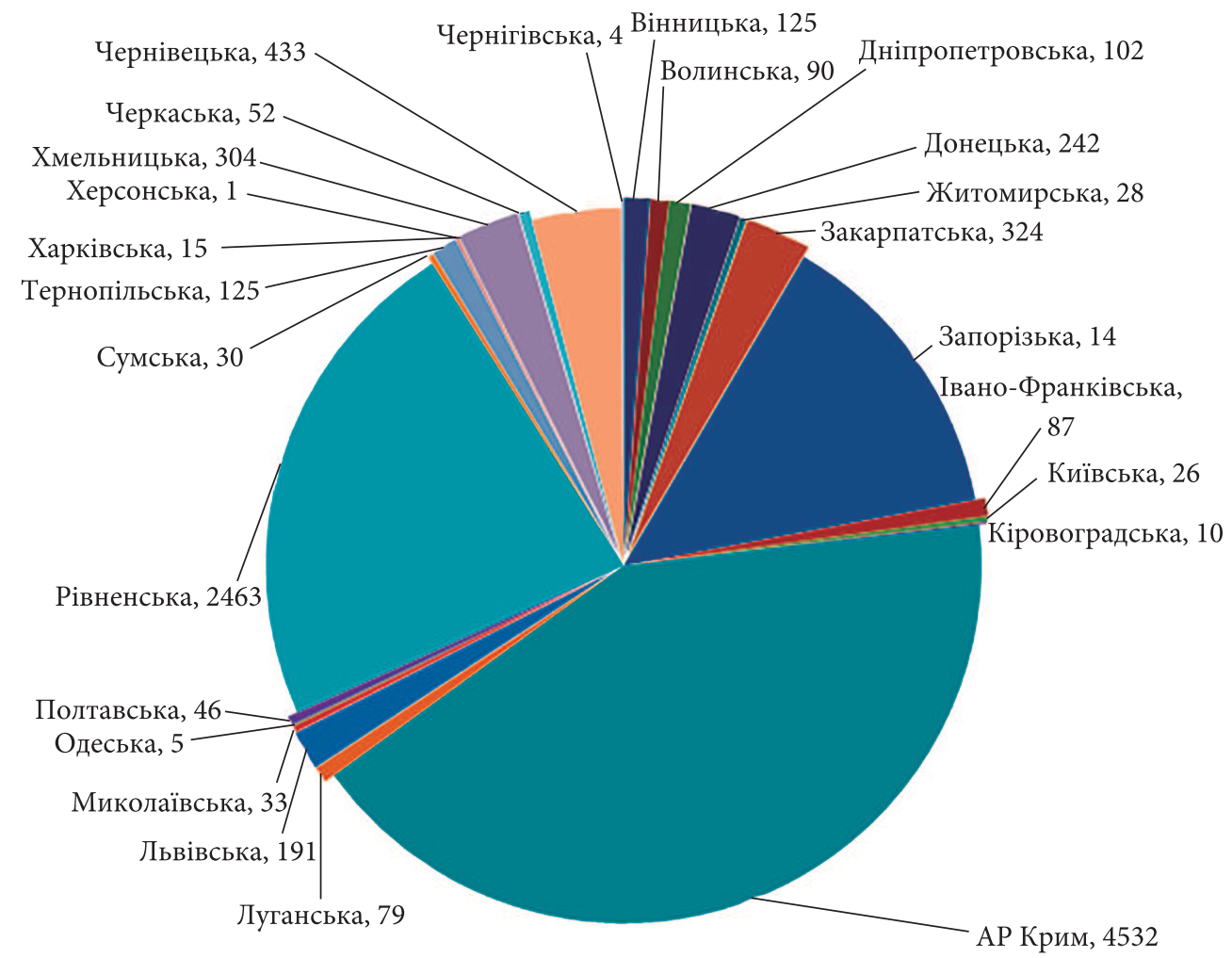

ків становить 0,6 \%. Палеонтологічні заказники взагалі у Кадастрі відсутні. Проте є палеонтологічна пам'ятка природи “Ділянка узбережжя Азовського моря” у Запорізькій області, що не відповідає ст. 3 Закону України "Про ПЗФ України”. Частка геологічних пам'яток природи становить 13 \% від кількості та 7 \% від площі всіх оголошених та внесених до Кадастру пам'яток.
Мала частка геологічних об’єктів ПЗФ свідчить, як правило, не про незначну кількість чи відсутність унікальних об'єктів геологічної спадщини на території регіону, а про недостатню роботу щодо їх охорони, збереження та популяризації. Це підтверджується відомостями інших джерел про об'єкти геологічної спадщини, привабливі як з наукової точки зору, так і для розвитку геотуризму. Так, у Рівненській 
області, відповідно до Кадастру, налічується чотири геологічних заказники та дві геологічні пам'ятки природи місцевого значення, а у базі даних УкрДГРІ зібрані відомості про більш ніж 20 “геологічних пам’яток” (Карта..., 2019). Схожа ситуація і в інших областях.

\section{Порядок надання геологічним об'сктам статусу об'сктів ПЗФ}

Офіційний статус об’єкта ПЗФ визначає його положення у правовій, адміністративній, науковій, культурній, економічній, політичній та інших сферах на державному та міжнародному рівнях. Проте лише після дотримання процедури створення чи оголошення, відповідно до Закону України “Про ПЗФ України”, цей статус поширюється на геологічний об'єкт. Після цього встановлюється відповідний режим охорони та організації території, визначаються та обгрунтовуються заходи охорони і використання, надаються кошти для реалізації проектних рішень.

Для надання геологічному об'єкту офіційного статусу об’єкта ПЗФ, встановлення відповідного режиму охорони та організації території необхідно витримати процедуру, передбачену Законом України “Про ПЗФ України”.

По-перше, підготувати клопотання про необхідність створення чи оголошення території або об’єкта ПЗФ певної категорії та подати їх на розгляд. Це можуть зробити облдержадміністрації, наукові установи чи будь-які заінтересовані особи. У клопотанні обгрунтовується необхідність заповідання, надається характеристика природоохоронної, наукової, естетичної та іншої цінності; інформація про місцезнаходження, розміри, характер використання, власників та користувачів; додається відповідний картографічний матеріал.

По-друге, розглянути клопотання щодо територій і об'єктів загальнодержавного значення Мінекоенергетики щодо місцевого значення - обласними або Київською міською держадміністраціями.

По-третє, у разі схвалення клопотання: а) погодити із власниками та первинними користувачами природних ресурсів у межах цих територій; б) розробити проекти створення заказників, пам'яток природи; в) передати ці проекти для прийняття рішення відповідно Президенту України (об’єкти загальнодержав- ного значення) або обласним (Київській міській) радам (об’єкти місцевого значення).

Зміна меж, категорії, скасування статусу територій та об'єктів ПЗФ проводиться на підставі відповідного експертного висновку в такій же послідовності. Така ж процедура дотримується і при резервуванні об'єктів до прийняття рішень про організацію чи оголошення. Тому, зважаючи на складність процедури оголошення, резервування та зміни характеристик об'єктів ПЗФ, раніше внесених до Кадастру, не зовсім доцільними є пропозиції деяких авторів щодо встановлення нових типів пам'яток, як “гідрогеологічні”, “геоморфологічні" тощо.

Відомості про створені чи оголошені рішенням Президента України об'єкти загальнодержавного, рішенням обласної ради - місцевого значення, вносяться до Кадастру, оприлюднення якого здійснюється один раз на 5 років (за станом на 1 січня відповідного року). У проміжні роки за рішенням Мінекоенергетики можуть оприлюднюватись додаткові відомості відповідно до змін у складі ПЗФ, що відбулись упродовж року (Про затвердження..., 2005; Державний..., 2013). На кожний заказник та пам'ятку природи розробляється Положення, що затверджується наказом Мінекоенергетики для об'єктів загальнодержавного значення, чи обласного управління Мінекоенергетики для об’єктів місцевого значення (Про затвердження..., 2018).

Участь фахівців-геологів, як “заінтересованих осіб”, у цьому процесі можлива при підготовці клопотань щодо оголошення геологічних об'єктів заказниками чи пам'ятками природи для подання їх на розгляд до обласних державних адміністрацій.

\section{Висновки}

Проведені дослідження виявили ряд проблемних питань щодо геологічних об'єктів ПЗФ.

1. Недосконалість термінології, некоректність та невідповідність їі не тільки науковим геологічним термінам, а й положенням законодавчих та нормативно-правових актів щодо ПЗФ. Основними причинами $є$ значна кількість різноманітних класифікацій “геологічних пам'яток”, не узгоджених із чинним законодавством, та відсутність участі фахівців-геологів у 
процедурі оголошення геологічних об’єктів об'єктами ПЗФ.

2. Низька питома вага геологічних об'єктів ПЗФ та нерівномірність їх розподілу по адміністративних областях України, що пов'язано із різним рівнем зацікавленості відповідних органів державної влади та місцевого самоврядування у збереженні та популяризації геологічної спадщини.

3. Досить складна процедура оголошення об'єктів ПЗФ та відсутність законодавчих чи нормативних положень щодо участі фахівців, в тому числі і геологів, в процедурі заповідання, що призводить до нефахового підходу до підготовки матеріалів, вибору назви, прийняття рішень щодо надання чи зміни статусу об'єкта ПЗФ, а також до незначної кількості об’єктів геологічної спадщини із таким статусом.

Для вдосконалення термінології та ідентифікації геологічних об’єктів ПЗФ, коректного формування набору відомостей щодо них пропонується уніфікована класифікація, що враховує як наукові, так і закріплені на законодавчому та нормативно-правовому рівні положення. При формуванні назви геологічного об'єкта доцільно використати назву підтипу (морфоскультура) та адміністративно-територіальну прив'язку (назва найближчого населеного пункту). Недопустимо використовувати некоректні назви геологічних об'єктів при подальшому заповіданні.
Для покращення ситуації із заповіданням об'єктів геологічної спадщини, надання їм статусу об'єктів ПЗФ із відповідним режимом охорони та підвищення рівня компетентності в прийнятті рішень, передбачити на нормативно-правовому рівні консалтингову та/або експертну участь фахівців-геологів у формуванні відомостей про об'єкт та підготовці клопотань про необхідність його оголошення; у розгляді клопотань та прийнятті рішень про їх схвалення; розробці (погодженні) проектів створення заказників та геологічних пам'яток природи, відповідних Положень.

Враховуючи, що Закон України "Про Про природно-заповідний фонд України” від 16.06.1992 № 2456-XII і зараз не обмежує участь фахівців-геологів у підготовці клопотань та поданні їх на розгляд відповідним органам державної влади, бажано активізувати діяльність у напрямах: а) ініціювання оголошення або хоча 6 резервування геологічних об’єктів, які ще не внесені до ПЗФ, заказниками (на ділянках скупчень відслонень вздовж річок, балок тощо) чи пам'ятками природи; б) розробки заходів щодо збереження еталонних ділянок геологічної будови окремих регіонів території України; в) тісної дієвої співпраці з відповідними органами державної влади та місцевого самоврядування, територіальними управліннями Мінекоенергетики, участі (за можливості) у відповідних експертних комісіях.

\section{СПИСОК ЛІТЕРАТУРИ}

Вертель В.В. Відслонення відкладів палеоцену - потенційні геологічні заповідні об'єкти Сумської області. Природничі науки. 2015. № 12. С. 49-56. URL: http://repository.sspu.sumy.ua/bitstream/123456789/3273/1/ Vertel.pdf. (Дата звернення: 10.04.2019).

Демчишин М.Г., Пилипчук О.М., Самойленко Л.В., Єлін В.М., Назаренко В.В., Дубииька А.В. Інженерно-геологічні фактори збереження геологічних пам’яток України. Геол. журн. 2011. № 3 (336). С. $73-77$.

Державний кадастр територій та об'єктів природно-заповідного фонду Украйни станом на 01.01.2013 / Міністерство екології та природних ресурсів України. URL: http://pzf.menr.gov.ua/пзф-україни/території-таоб’єкти-пзф-україни.html. (Дата звернення: 10.04.2019).

Карта геологічних пам'яток України. URL: http://ukrdgri.gov.ua/uk/landmark-map/. (Дата звернення 10.04.2019). Люта Н.Г., Саніна І.В., Лютий Г.Г. Ще раз про геологічні пам’ятки. Геологічна спадщина. 2012. № 1. С. 39-44. URL: http://ukrdgri.gov.ua/wp-content/uploads/2016/07/mru_01_2012_12.pdf. (Дата звернення: 10.04.2019).

Палюх В.М. Розвиток поняття “геологічна пам'ятка природи”. Наук. зап. СумДПу імені А.С. Макаренка. Сер. Геогр. науки. 2010. Вип. 1. С. 150-154. URL: http://scinotesgeo.at.ua/Volume_1/palukh.pdf. (Дата звернення: 10.04.2019).

Про затвердження Інструкиії про зміст та складання документації Державного кадастру територій та об'єктів природно-заповідного фонду України: Наказ Міністерства охорони навколишнього природного середовища України N 67 від 16.02.2005. База даних “Законодавство України” / ВР України. URL: https://zakon. rada.gov.ua/laws/show/z0298-05. (Дата звернення: 10.04.2019). 
Про затвердження Методичних рекомендацій: Наказ Міністерства екології та природних ресурсів України № 309 від 21.08.2018. База даних “Законодавство України” / ВР України. URL: https://zakon.rada.gov.ua/rada/ show/v0309737-13\#n11. (Дата звернення: 10.04.2019).

Про затвердження Методичних рекомендацій щьодо розроблення проектів створення природних територій та об'єктів природно-заповідного фонду України: Наказ Міністерства екології та природних ресурсів України № 306 від 21.08.2018. База даних “Законодавство України” / ВР України. URL: https://zakon.rada.gov.ua/rada/ show/v0306737-18. (Дата звернення: 10.04.2019).

Про природно-заповідний фонд України: Закон від 16 червня 1992 року № 2456-ХІІ. База даних “Законодавство України” / ВР України. URL: https://zakon.rada.gov.ua/laws/show/2456-12. (Дата звернення: 10.04.2019).

Самойленко Л.В., Дубицька А.В. Класифікація геологічних пам'яток за інженерно-геологічними ознаками. Геол. журн. 2012. № 1 (338). С. 91-98.

Самойленко Л.В., Дубицька А.В. Вплив інженерно-геологічних процесів на стан геологічних пам'яток. Вісн. Наи. наук.-природ. музею. 2011. № 9. С. 48-57.

Форма 4 ДКПЗФ (станом на 01.01.2017). URL: http://pzf.menr.gov.ua/пзф-україни/території-та-об’єкти-пзфукраїни.htm. (Дата звернення: 10.04.2019).

Надійшла до редакції 30.07.2019 Надійшла у ревізованій формі 17.04.2020 Прийнята 25.04.2020

\section{REFERENCES}

About the Nature Reserve Fund of Ukraine: Law of June 16, 1992 № 2456-XII. Database "Legislation of Ukraine”. The Verkhovna Rada of Ukraine. Retrieved from: https://zakon.rada.gov.ua/laws/show/2456-12 (in Ukrainian).

Demchyshyn M.G., Pylypchuk O.M., Samoilenko L.V., Yelin V.M., Nazarenko V.V., Dubitskaya A.V., 2011. Engineering and geological factors of conservation of geological monuments of Ukraine. Geologichnyy zhurnal, № 3 (336), pp. 73-77 (in Ukrainian).

Form 4 SCNRF (as of January 1, 2017). Retrieved from: http://pzf.menr.gov.ua/пзф-україни/території-та-об’єктипзф-україни.html (in Ukrainian).

Luta N.G., Sanina I.V., Lyuty G.G., 2012. Once more about geological sights. Geologichna spadshchyna, №. 1, pp. 39-44. Retrieved from: http://ukrdgri.gov.ua/wp-content/uploads/2016/07/mru_01_2012_12.pdf (in Ukrainian).

On approval of the Instruction on the content and documentation of the state cadastre of territories and objects of the nature reserve fund of Ukraine: Order of the Ministry of Environmental Protection of Ukraine № 67 of February 16, 2005. Database "Legislation of Ukraine". The Verkhovna Rada of Ukraine. Retrieved from: https://zakon.rada.gov.ua/ laws/show/z0298-05 (in Ukrainian).

On approval of the Methodological recommendations: Order of the Ministry of Ecology and Natural Resources of Ukraine № 309 dated August 21, 2013 // Database "Legislation of Ukraine". The Verkhovna Rada of Ukraine. Retrieved from: https://zakon.rada.gov.ua/rada/show/v0309737-13\#n11 (in Ukrainian).

On approval of Methodological Recommendations for the Development of Natural Resource Development Projects and Natural Reserve Funds in Ukraine: Order of the Ministry of Ecology and Natural Resources of Ukraine № 306 dated August 21, 2018. Database of Ukrainian Legislation. Verkhovna Rada of Ukraine. Retrieved from: https://zakon. rada.gov.ua/rada/show/v0306737-18 (in Ukrainian).

Paluk V.M., 2010. The development of the concept of "Geological monument of nature". Naukovi zapysky SumDPU imeni A.S. Makarenka. Seriya Geografichni nauky, issue 1, pp. 150-154 (in Ukrainian).

State Cadastre Territories and objects of natural reserve fund of UKRAINE, as of 01/01/2018. Ministry of Ecology and Natural Resources of Ukraine. Retrieved from: http://pzf.menr.gov.ua/пзф-україни/території-та-об'єкти-пзфукраїни.html (in Ukrainian).

Samoylenko L.V., Dubytskaya A.V., 2012. The classification of geosites according to the engineering-geological features. Geologichnyy zhurnal, № 1 (338), pp. 91-98 (in Ukrainian).

Samoylenko L.V., Dubytskaya A.V., 2011. The influence of engineering geological processes on the condition of geological sites. Visnyk Natsionalnogo naukovo-pryrodnychogo muzeyu, № 9, pp. 48-57 (in Ukrainian).

The map of geological landmarks of Ukraine. Retrieved from: http://ukrdgri.gov.ua/uk/landmark-map/ (in Ukrainian)

Vertel V.V., 2015. Outcrop of deposits of Paleocene - potential geological natural reserved objects of Sumy region. Prirodniči nauky, № 12, pp. 49-56. Retrieved from: Retrieved from: http://repository.sspu.sumy.ua/bitstream/ 123456789/3273/1/Vertel.pdf (in Ukrainian).

Received 30.07.2019

Received in revised form 17.04.2020

Accepted 25.04.2020 


\author{
L.V. Samoilenko \\ Institute of Geological Sciences of NAS of Ukraine, Kyiv, Ukraine, \\ E-mail: samoilenko2017@ukr.net
}

\title{
GEOSITES AS OBJECTS OF NATURAL RESERVE FUND (PROBLEMATIC ISSUES)
}

Based on the data of the State Cadaster of Territories and Objects of the Natural Reserve Fund of Ukraine, the peculiarities of the distribution of geosites over the territories of administrative-territorial units have been analyzed and categories, types, significance and the degree of value have been established. The ways of reconciliation of classifications of geological sites with the legislative and regulatory base pertinent to the nature reserve fund of Ukraine have been proposed. The procedure for legislative establishing of geosites has been analyzed and ways of cooperation with the regional departments of the Ministry of Environment for their promotion and protection have been proposed. With the establishment, the object of the nature reserve fund at the legislative level receives the category - "natural monument", the type of origin "geological". Depending on the significance (national or local) and value (international, national, regional, local) of the geological monument of nature, a regime for its protection is established. Based on these characteristics, the object is entered into the State Cadastre of Territories and Nature Reserve Fund Objects. In order to harmonize the existing classifications of different authors with legislative and regulatory acts on the Nature Reserve Fund of Ukraine, the following is proposed. According to the geomorphological features of the subtype of geosites, it is proposed to adopt the unified name of the morphosculpture indicated in the State Cadastre and establish five subtypes: rock outlier; exposure; underground cavity; water body; others. The class is distinguished based on physicomechanical properties of the soils of the natural monument, on which the intensity of destruction and, accordingly, the direction of the conservation measures depend on: easily wetted; readily soluble; medium strength; durable. According to engineering-geological processes that took part in the formation (exposure) of the monument, the following subclasses are proposed: denudation; erosiondenudation; erosive; abrasion, karst-suffosion; technogenic, etc. It is advisable to further separate the geological monuments according to the subject of research: mineralogical, petrographic, lithological, stratigraphic, paleontological, etc., which is proposed by other authors.

Keywords: geosites; objects of Natural Reserve Fund; State cadaster; classification; protection of geosites.

\section{Л.В. Самойленко}

Институт геологических наук НАН Украины, Киев, Украина, E-mail: samoilenko2017@ukr.net

\section{ГЕОЛОГИЧЕСКИЕ ПАМЯТНИКИ ПРИРОДЫ КАК ОБЪЕКТЫ ПРИРОДНО-ЗАПОВЕДНОГО ФОНДА (ПРОБЛЕМНЫЕ ВОПРОСЫ)}

На основании данных Государственного кадастра территорий и объектов природно-заповедного фонда Украины установлены особенности распределения геологических объектов по административно-территориальным единицам по категориям, типам объектов, значению и степени ценности. Наибольшая часть геологических от общего количества объявленных памятников природы находится в Житомирской, Черновицкой и Донецкой областях. Проанализирован порядок объявления геологических памятников и предложена оптимизация сотрудничества с соответствующими государственными органами для их популяризации, охраны и сохранения. Во время объявления объект природно-заповедного фонда на законодательном уровне получает категорию - “памятник природы”, тип по происхождению - “геологический”. В зависимости от значения (общегосударственное или местное) и ценности (международная, национальная, региональная, местная) геологического памятника природы устанавливается режим его охраны. По этим признакам объект вносится в Государственный кадастр территорий и объектов природно-заповедного фонда. С целью согласования существующих классификаций разных авторов с законодательными и нормативно-правовыми актами по природно-заповедному фонду Украины предлагается следующее. По геоморфологическим признакам подтипа геологических памятников принять унифицированное название морфоскульптуры, указаное в Государственном кадастре, и установить пять подтипов: останец; обнажение; подземная полость; водный объект; другие. Признаком класса принять инженерно-гелогические характеристики пород памятника природы, от которых зависит интенсивность разрушения и, соответственно, направление охранных мероприятий: легкоразмываемые; легкоразмокаемые; легкорастворимые; средней прочности; прочные. По инженерно-геологическим процессам, которые принимали участие в образовании (раскрытии) памятника, установить подклассы: денудационные; эрозионно-денудационные; эрозионные; абразионные, карстово-суффозионные; техногенные и т.п. Целесообразно дальнейшее разделение геологических памятников по предмету исследований: минералогический, петрографический, литологический, стратиграфический, палеонтологический и т.п., которое предлагают и другие авторы.

Ключевые слова: геологические памятники природы; объекты природно-заповедного фонда; Государственный кадастр; классификация. 